\title{
Effect of Short- and Long-Term Administration of Baclofen on Spatial Learning and Memory in Rats
}

\author{
M. HOLAJOVA ${ }^{1}$, M. FRANEK ${ }^{1}$ \\ ${ }^{1}$ Department of Normal, Pathological and Clinical Physiology, Third Faculty of Medicine, Charles \\ University, Prague, Czech Republic
}

Received November 13, 2016

Accepted June 19, 2017

On-line November 10, 2017

\section{Summary}

Baclofen is the only clinically available metabotropic $\mathrm{GABA}_{B}$ receptor agonist. In our experiment, we tested the hypothesis that long-term baclofen administration can impair learning and memory in rats. The experiment consisted of three parts. In the first part of the study the drug was administered simultaneously with the beginning of the behavioral tests. In the second and third part of the experiment baclofen was administered daily for 14 days and for one month before the tests. In each part of the experiment, adult rats were randomly divided into four treatment groups. Three groups were given an injection of baclofen at doses of $1 \mathrm{mg} / \mathrm{kg}, 5 \mathrm{mg} / \mathrm{kg}, 10 \mathrm{mg} / \mathrm{kg}$, while the fourth group was injected with saline. The injections were given after each session. Spatial learning and memory were tested using the Morris water maze, involving three types of tests: Acquisition, Probe, and Re-acquisition. This work reveals that baclofen did not affect spatial learning at any of the tested doses and regardless of the length of administration. Memory was observed to be affected, but only at the highest dose of baclofen and only temporarily. This conclusion is in line with previously published clinical cases.

\section{Key words}

Baclofen • Spatial learning • Memory • Short-term administration - Long-term administration

\section{Corresponding author}

M. Holajova, Department of Normal, Pathological and Clinical Physiology, Third Faculty of Medicine, Charles University in Prague, Ke Karlovu 4, 12000 Prague 2, Czech Republic. E-mail: ferdova.monika@seznam.cz

\section{Introduction}

$\mathrm{GABA}_{\mathrm{B}}$ receptor is the main inhibitory metabotropic receptor in the central nervous system (CNS) of mammals. These receptors belong to the G protein-coupled receptor (GPCR) family (also known as 7 transmembrane domain receptors). The $\mathrm{GABA}_{\mathrm{B}}$ receptor is made from 2 subunits $\left(\mathrm{GABA}_{\mathrm{B} 1}\right.$ and $\left.\mathrm{GABA}_{\mathrm{B} 2}\right)$ to form a heterodimer. The subunits have different functions. The $\mathrm{GABA}_{\mathrm{B} 1}$ subunit binds $\gamma$-aminobutyric acid (GABA) and other ligands. GABA $\mathrm{B}_{2}$ is responsible for interactions with the effector $G$ protein. $\mathrm{GABA}_{\mathrm{B}}$ receptors are found presynaptically and postsynaptically. The activation of presynaptic receptors leads to inhibition of mediator release by blocking voltage-gated calcium channels, whereas postsynaptic receptors lead to increased activity of potassium channels and inhibition of adenylyl cyclase (Benarroch 2012, Bettler et al. 2004, Bowery 2010, Bowery et al. 2002).

Baclofen ( $\beta$-chlorophenyl - GABA, Lioresal) is the only clinically available $\mathrm{GABA}_{\mathrm{B}}$ receptor agonist and is used as an antispastic agent and a central, muscle relaxant. Baclofen is used as the first-line treatment for spasticity and skeletal muscle rigidity due to traumatic spinal cord injury, cerebral palsy, multiple sclerosis, and amyotrophic lateral sclerosis (Bettler et al. 2004). Baclofen is also known to have analgesic effects. There have been many studies using experimental models of acute and chronic neuropathic pain (Franek and Vaculin 2009, Franek et al. 2004); however, in human medicine its use as an anti-nociceptive is only indicated for the treatment of trigeminal neuralgia (Benarroch 2012). 
Baclofen can be delivered either orally or intrathecally. Orally administered baclofen is often not well tolerated by patients, because to achieve therapeutic effects requires the use of high doses; however, even at high doses penetration of the blood-brain barrier (BBB) is poor. The introduction of intrathecal administration via pumps, which bypasses the $\mathrm{BBB}$, has reduced the occurrence of adverse effects since lower concentrations can be used to achieve therapeutic effects (Bowery 2006).

$\mathrm{GABA}_{\mathrm{B}}$ receptors are widely distributed within the CNS. They are well-represented in the hippocampus, which is an essential structure for spatial learning and memory (Benarroch 2012). There have been studies on $\mathrm{GABA}_{\mathrm{B}}$ receptor ligands and their participation in learning and memory processes (reviewed in Bowery et al. 2002). The effect of $\mathrm{GABA}_{\mathrm{B}}$ receptors agonists on cognitive processes using animal models have turned out to be rather inconsistent. Laboratory animal studies have reported that baclofen dose-dependently disrupts learning and memory in rodents when administered systemically (followed by behavioral testing e.g. avoidance condition test (Castellano and McGaugh 1991, Swartzwelder et al. 1987), Morris water maze test (McNamara and Skelton 1996, Nakagawa et al. 1995, Nakagawa and Takashima 1997), Place avoidance test (Stuchlik and Vales 2009), or has effects after intra-hippocampal application (Arolfo et al. 1998, Zarrindast et al. 2002). However, there are also studies that demonstrated learning and memory facilitation (Georgiev et al. 1988, Saha et al. 1993) or no effect on acquisition and memory processes in systematic (Car and Wiśniewski 1998, Sidel et al. 1988), or intrathecal administration (Nomura et al. 2012). In contrast, $\mathrm{GABA}_{\mathrm{B}}$ receptor antagonists improved performance on a number of different cognitive test (e.g. passive and active avoidance, special learning, and memory; Jacobson et al. 2007). There are also clinical reports of baclofen interference in memory processes. Memory impairment has been described for oral administration (e.g. Sandyk and Gillman 1985), where oral baclofen induced memory impairment leading to the inability to remember or recognize names of familiar persons and places) and also for intrathecal administration, e.g. Grande et al. (2008). They describe an unusual case of memory impairment associated with intrathecal baclofen in which episodes of amnesia occurred repeatedly and each episode met the criteria for a neurological entity known as transient global amnesia (TGA).

The target of this research was to analyze the impact of short-term and long-term administration of baclofen on spatial learning and memory processes in rats.

\section{Methods}

\section{Animals}

Adult male (300-400 g) Albino Wistar rats from Charles River Laboratories International, Inc. (ANLAB; Prague, Czech Republic) were used. The animals were housed in groups of four rats per cage. Food and water were continuously available during the experiment. The light cycle was set to 12-hour light/12-hour dark. All the experiments were conducted during the light phase of the cycle.

The procedures for animal experimentation utilized in this study were reviewed and approved by the Institutional Animal Care and Use Committee and were in agreement with the Czech Government Requirements under the Policy of Human Care of Laboratory Animals (No. 246/1992) and with subsequent regulations by the Ministry of Agriculture of the Czech Republic.

\section{Groups and drugs injections}

The experiment consisted of three parts. In the first part of the study baclofen was administered simultaneously with the beginning of the behavioral tests in the Morris water maze (MWM) (0D). In the second and third parts of the experiment baclofen was administered for 14 days (14D) and for one month (1M) before testing (Fig. 1). Thirty-two animals were used for each part of the experiment. Before the beginning of behavioral testing, adult male rats were randomly divided into four treatment groups ( $\mathrm{n}=8$ per group). Three groups were injected with baclofen at doses of $1 \mathrm{mg} / \mathrm{kg}, 5 \mathrm{mg} / \mathrm{kg}$, and $10 \mathrm{mg} / \mathrm{kg}$ (baclofen was in a solution of $10 \%$ gum acacia in saline); the fourth group was injected with the saline vehicle only (Control $-1 \mathrm{ml} / \mathrm{kg}$; all drugs from Sigma-Aldrich). The drugs were administered subcutaneously (s.c.). On the days when the behavioral tests were performed all injections were administered after finishing behavioral testing.

\section{Apparatus}

The Morris water maze was used to test spatial learning and memory. The MWM consisted of a circular tank $\left(2 \mathrm{~m}\right.$ in diameter), filled with water $\left(21 \pm 1{ }^{\circ} \mathrm{C}\right)$. On the rim of the tank were four marks that were 90 degrees apart (North - N, South - S, East - E, West - W). Thus, 
the maze was divided into four quadrants. The hidden escape platform (clear Plexiglas, $13 \mathrm{~cm}$ in diameter) was submerged approximately $1.0 \mathrm{~cm}$ below the surface of the water. The platform was placed in the center of northeast quadrant (Fig. 2). Various visual cues, in form of pictures, were situated on the testing room walls for better orientation in the maze. Trials were automatically recorded using an EthoVision 6 and 10 video-tracking system (Noldus Information Technology, Netherlands). In the present study three types of tests were used: "Acquisition," "Probe test," and "Re-acquisition" as described previously (Macúchová et al. 2013).

A OD part of study

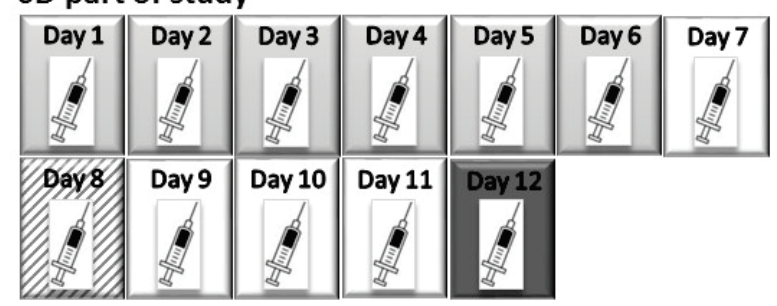

B 14D part of study

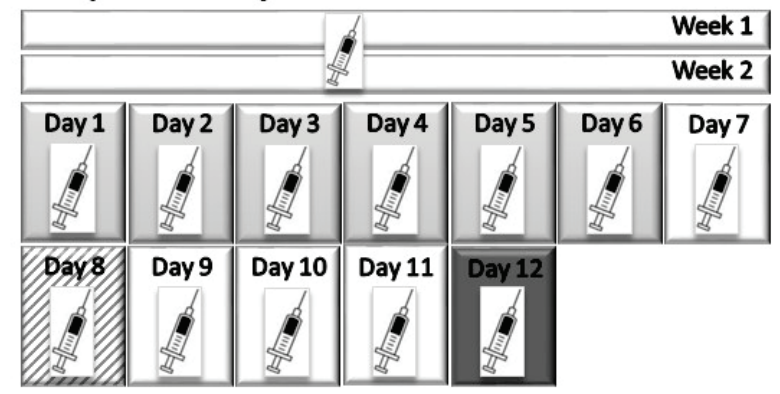

C $1 \mathrm{M}$ part of study

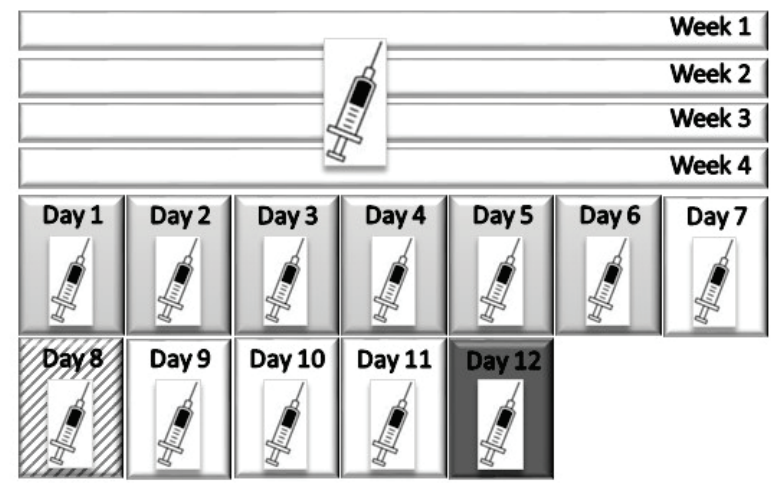

Fig 1. Study schematic and MWM testing. (A) OD part of study: Baclofen administered simultaneously with beginning of behavioral MWM testing. (B) 14D part of study: Baclofen injected for 14 days before MWM testing. (C) $1 \mathrm{M}$ part of study: Animals were treated with baclofen for 1 month before MWM testing. Baclofen was administered each day (picture of syringe). The light grey rectangle represents 6 days of behavioral testing during the learning phase, the hatched rectangle represents the probe test $\left(8^{\text {th }}\right.$ day) and the dark grey rectangle $\left(12^{\text {th }}\right.$ day) represents the Re-acquisition task. White rectangle symbolize the days without behavioral test (drug administration only).

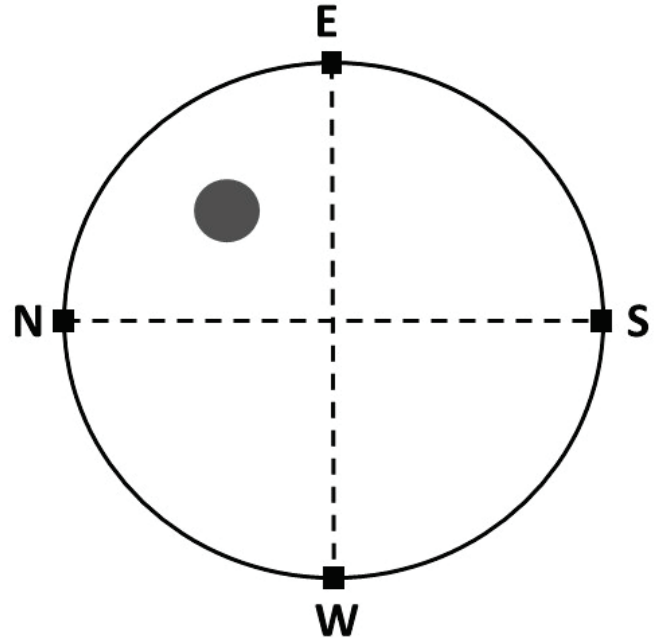

Fig 2. Image of the MWM pool: $\mathrm{N}$ - North, $\mathrm{S}-$ South, $\mathrm{E}$ - East, $\mathrm{W}$ - West represent the four starting point on the rim of maze. Thus, the maze was divided into four quadrants. The hidden escape platform (grey circle) was placed in the center of northeast quadrant.

\section{Acquisition}

Over a period of 6 consecutive days the animals were trained to locate the hidden platform. Each day the rats performed eight trials from four different starting positions $(\mathrm{N}, \mathrm{S}, \mathrm{E}, \mathrm{W})$ in the same order. The task of the rats was to escape from the water onto the hidden platform within $60 \mathrm{~s}$. If the rat did not locate the platform during this time, it was guided by the experimenter to the platform. The rats were allowed to remain on the platform for $30 \mathrm{~s}$ before being removed. The position of the platform was the same in all trials. For each trial the rat was placed in the water facing the pool wall. The following parameters were automatically measured: latency (time to reach the hidden platform) [s], total distance $[\mathrm{cm}]$, and swim speed $[\mathrm{cm} / \mathrm{s}]$.

\section{Probe test}

The Probe test was conducted on the $8^{\text {th }}$ day of experiment. Rats were left to swim in the pool without an escape platform for $60 \mathrm{~s}$. The starting position was north (N) for all rats. The frequency of incursions into the northeast quadrant, which was where the escape platform had been located (the correct quadrant) were measured.

In the Probe test, the times spent in northeast quadrant were recorded using the video-tracking system. Other analyzed parameters included frequency of incursions and time spent in the opposite (southwest) quadrant and swim speed.

Moreover, heat maps were created for particular groups. These maps showed the frequency of animal movements during testing in shades of gray. 


\section{Re-acquisition}

The Re-acquisition test was conducted on the $12^{\text {th }}$ experimental day. Testing was the same as that used in the Acquisition. The task was to find the platform within $60 \mathrm{~s}$. The platform was located in the same position as in the Acquisition. Rats were exposed to 8 trials starting from four different positions. The following parameters were analyzed: latency [s], total distance $[\mathrm{cm}]$, and swim speed $[\mathrm{cm} / \mathrm{s}]$.

\section{Statistical analysis}

Statistical analysis was carried out using Statistica 12.0 (StatSoft Inc., USA). Data are expressed as mean \pm S.E.M. The data obtained from the Acquisition were analyzed using three-way analysis of variance (ANOVA) and one-way ANOVA with multilevel repeated measures (days x trials/days). One-way ANOVA for repeated measures (trials/days) was used to analyze the data from the Re-acquisition test. The Probe test data were analyzed using one-way ANOVA. For post hoc comparisons the Fishers Least Significant Difference (LSD) test was used. In every test, differences were considered significant if $\mathrm{p}<0.05$.

\section{Results}

\section{Acquisition}

When drug administration started simultaneously with beginning of behavioral testing in the MWM (0D), there were no significant differences among groups with regard to latency in reaching the hidden platform $[\mathrm{F}(3,28)=0.25, \mathrm{p}=0.86]$, the distance $[\mathrm{F}(3,28)=0.30, \quad \mathrm{p}=0.82], \quad$ or $\quad$ swimming speed $[\mathrm{F}(3,28)=0.30, \mathrm{p}=0.82]$.

In the $14 \mathrm{D}$ part of the study, baclofen was given for 14 days before MWM testing. The monitored parameters (latency, distance, and swim speed) were not affected by baclofen treatment (the main group effects were: latency: $\quad \mathrm{F}(3,28)=1.28, \quad \mathrm{p}=0.30$; distance: $\mathrm{F}(3,28)=2.53, \quad \mathrm{p}=0.08 ; \quad$ swim speed: $\mathrm{F}(3,28)=1.66$, $\mathrm{p}=0.20]$.

In the $1 \mathrm{M}$ part of the study (baclofen given daily for 1 month before MWM testing) baclofen was also found to have no effect: latency $[\mathrm{F}(3,28)=0.48, \mathrm{p}=0.70]$, distance [distance: $\mathrm{F}(3,28)=0.22, \mathrm{p}=0.88$ ] and speed of $\operatorname{swim}[\mathrm{F}(3,28)=1.50, \mathrm{p}=0.24]$.

All animals in all parts of study (0D, 14D and $1 \mathrm{M})$, regardless of drug treatment demonstrated learning ability over the 6-day training period as shown by decreases in latency [0D: $\mathrm{F}(5,140)=92.55, \mathrm{p}<0.0001$; 14D: $\mathrm{F}(5,140)=71.93, \mathrm{p}<0.0001 ; 1 \mathrm{M}: \mathrm{F}(3,28)=0.48$, $\mathrm{p}=0.70]$, and distance [0D: $\mathrm{F}(5,140)=88.84, \mathrm{p}<0.0001$; 14D: $\mathrm{F}(5,140)=70.83, \mathrm{p}<0.0001 ; 1 \mathrm{M}: \mathrm{F}(5,140)=116.84$, $\mathrm{p}<0.0001]$. There were no significant differences among the groups in the particular day (day $x$ groups) in both (latency and distance) parameters (data not shown).

\section{Probe test}

In the $0 \mathrm{D}$ part of the study, analysis of data from the Probe test showed a significant main effect regarding time spent and frequency of incursions into the quadrant where the hidden platform had been located (correct quadrant) during the learning phase [time $\mathrm{F}(3,28)=4.07$, $\mathrm{p}=0.02$, frequency $\mathrm{F}(3,28)=6.23, \mathrm{p}=0.002]$. Post hoc comparison revealed that rats treated with the highest dose of baclofen $(10 \mathrm{mg} / \mathrm{kg})$ spent less time in the correct quadrant and had fewer incursions relative to the control group (time $\mathrm{p}=0.006$, frequency $\mathrm{p}=0.0004$ ) and groups treated with lower doses of baclofen (group B $1 \mathrm{mg} / \mathrm{kg}$ : time $\mathrm{p}=0.005$, frequency $\mathrm{p}=0.01$; group $\mathrm{B} 5 \mathrm{mg} / \mathrm{kg}$ : time $p=0.02$, frequency $p=0.002$; Fig. $3 \mathrm{~A}$ ). As for the opposite quadrant - the animals exposed to baclofen at a dose of $10 \mathrm{mg} / \mathrm{kg}$ preferred it significantly more compared to the control group (time: $\mathrm{p}=0.005$, frequency $\mathrm{p}=0.002$ ), as well as the group treated with baclofen at a dose of $1 \mathrm{mg} / \mathrm{kg}$ (time: $\mathrm{p}=0.002$, frequency $\mathrm{p}=0.01$ ) and $5 \mathrm{mg} / \mathrm{kg}$ (time: $p=0.007$, frequency $p=0.005$; Fig. $3 B$ ). Furthermore, the $0 \mathrm{D}$ animals group treated with the highest doses of baclofen $(10 \mathrm{mg} / \mathrm{kg})$ spent $1 / 4$ of the total time in the target quadrant and the opposite quadrant, which suggest randomly swimming of the animals. The groups treated with lower dose of baclofen ( 1 and $5 \mathrm{mg} / \mathrm{kg}$ ) were not significantly different from the controls.

There were no significant differences among group relative to swim speed $[\mathrm{F}(3,28)=0.38, \mathrm{p}=0.77]$.

In the $14 \mathrm{D}$ and $1 \mathrm{M}$ parts of the study, baclofen did not affect any of the tested parameters. Heat maps (Fig. 4) show the differences in time spent in various quadrants of the MWM. In the 0D part of the study, the control group and groups treated with baclofen at $1 \mathrm{mg} / \mathrm{kg}$ and $5 \mathrm{mg} / \mathrm{kg}$ yielded similar results, but animals treated with baclofen at $10 \mathrm{mg} / \mathrm{kg}$ spent less time in the correct quadrant. In the 14D and $1 \mathrm{M}$ parts of the study, in all groups we obtained similar results.

\section{Re-acquisition}

Analysis of data showed a significant main effect regarding baclofen exposure on latency 
$[\mathrm{F}(3,28)=3.31, \mathrm{p}=0.04]$ and distance $[\mathrm{F}(3,28)=3.27$, $\mathrm{p}=0.04]$.

In the $0 \mathrm{D}$ part of the study, post hoc comparisons revealed that rats treated with the highest dose of baclofen $(10 \mathrm{mg} / \mathrm{kg})$ had longer latency relative to controls ( $\mathrm{p}=0.02$; Fig. $5 \mathrm{~A}$ ). Distance data also showed that baclofen had a negative impact (Fig. 5B).

A

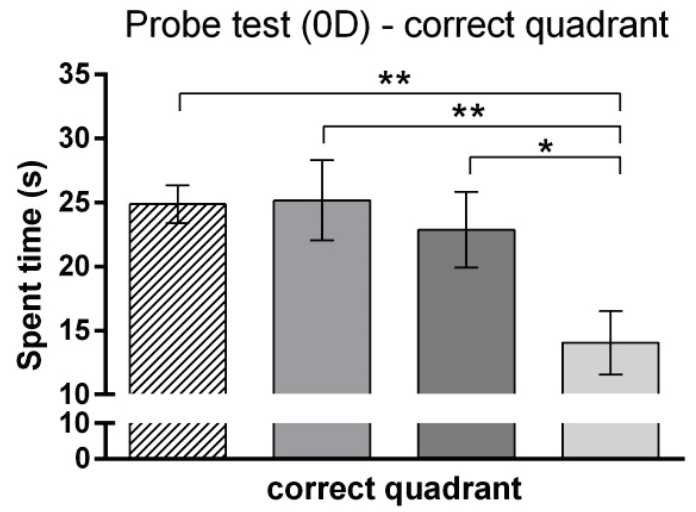

B

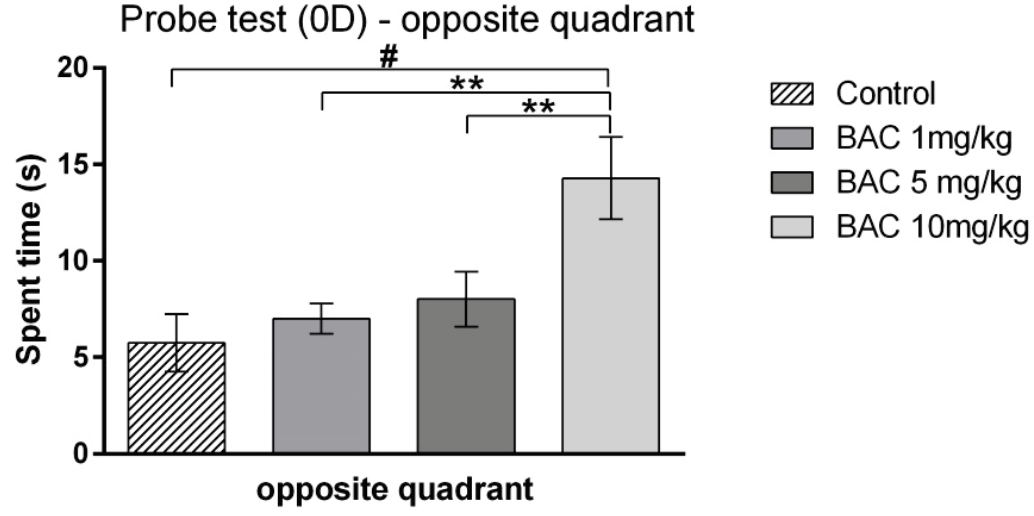

Control

A

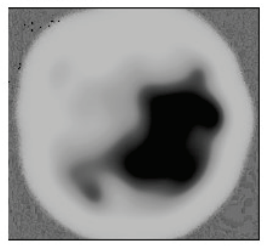

B

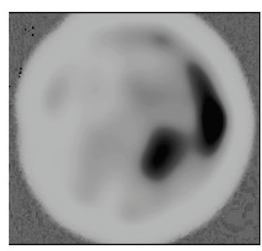

C

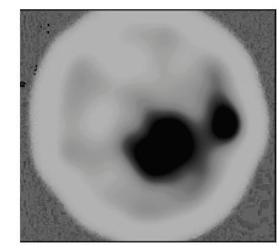

BAC $1 \mathrm{mg} / \mathrm{kg}$
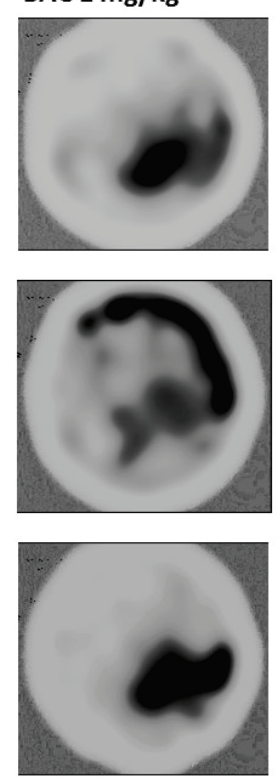

BAC $5 \mathrm{mg} / \mathrm{kg}$
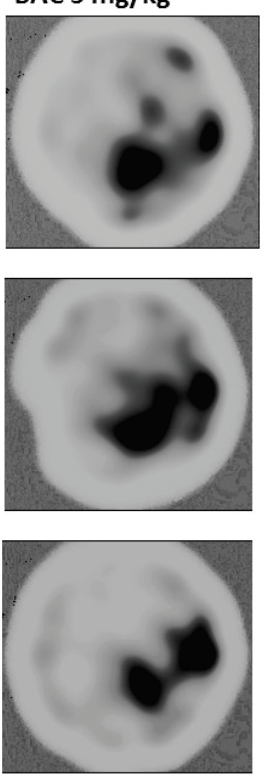

Control

BAC $1 \mathrm{mg} / \mathrm{kg}$

BAC $5 \mathrm{mg} / \mathrm{kg}$

BAC $10 \mathrm{mg} / \mathrm{kg}$
Fig 3. The Probe test in the $O D$ part of the study: Duration of animals in the quadrant where the platform had been located during the learning phase (A) and in the opposite quadrant (southwest quadrant, B). Data are expressed as mean $\pm \mathrm{SEM}$, $\mathrm{n}=8, * \mathrm{p}<0.05, * * \mathrm{p}<0.01,{ }^{*} \mathrm{p}<0.001$.
BAC $10 \mathrm{mg} / \mathrm{kg}$
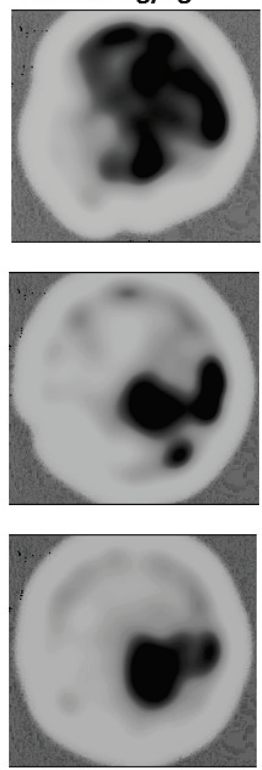

Fig 4. Heatmaps of the Probe test in the $0 D, 14 D$ and $1 M$ part of study. The shade of grey show where the animal spent time during the test (the darker the grey the longer the time spent in that location). 
A

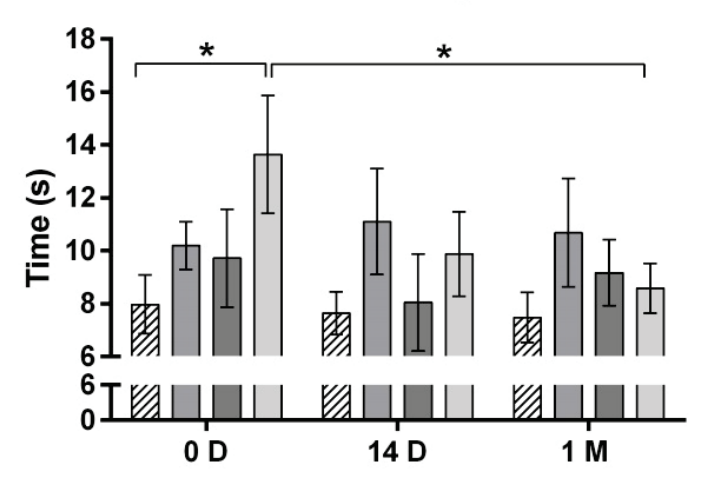

B

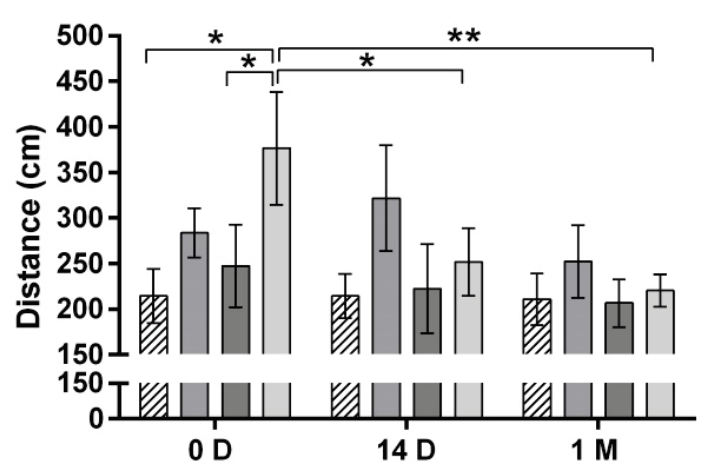

DIS Control

BAC $1 \mathrm{mg} / \mathrm{kg}$

BAC $5 \mathrm{mg} / \mathrm{kg}$

$B A C 10 \mathrm{mg} / \mathrm{kg}$
Fig 5. Performance on the Reacquisition task - effect of doses of baclofen $(1 \mathrm{mg} / \mathrm{kg}, 5 \mathrm{mg} / \mathrm{kg}$, $10 \mathrm{mg} / \mathrm{kg}$ ) in the three parts of the study (OD, 14D, 1M): (A) Latency to reach the hidden platform: OD part of study - the animals treated with the highest dose of baclofen $(10 \mathrm{mg} / \mathrm{kg})$ had longer latency than the control group. The $10 \mathrm{mg} / \mathrm{kg}$ Baclofen group of the OD part of the study needed significant longer time to reach hidden platform relative to $10 \mathrm{mg} / \mathrm{kg}$ baclofen group in the $1 \mathrm{M}$ part of the study. (B) Distance traveled: In the OD part of the study, animals treated baclofen at a dose of $10 \mathrm{mg} / \mathrm{kg}$ had traveled significantly longer distances than the control group and the $5 \mathrm{mg} / \mathrm{kg}$ baclofen group. Rats given baclofen at a dose of $10 \mathrm{mg} / \mathrm{kg}$ only during behavioral testing in MWM (OD) traveled longer distances relative to rats treated for 14day (14D) and 1 month (1M) before testing in the MWM. Results are presented as average of all 8 trials in day 12 . Values are mean \pm SEM, $n=8$, $* \mathrm{p}<0.05$, ** $\mathrm{p}<0.01$.
Furthermore, post hoc comparisons revealed that the $0 \mathrm{D}$ animal group treated with the highest dose of baclofen $(10 \mathrm{mg} / \mathrm{kg})$ possessed longer latency relative to the $1 \mathrm{M}$ group ( $\mathrm{p}=0.04$; Fig. $5 \mathrm{~A}$ ). Total distance post hoc comparisons showed that the $0 \mathrm{D}$ animals treated with baclofen at a dose of $10 \mathrm{mg} / \mathrm{kg}$ traveled longer total distances relative to the $14 \mathrm{D}(\mathrm{p}=0.04)$ and $1 \mathrm{M}(\mathrm{p}=0.01)$ animals (Fig. 5B).

An overall ANOVA on swim speed data showed no significant group difference $[F(3,27)=1.47, p=0.25]$.

\section{Discussion}

In our experiments we tested the hypothesis that long-term baclofen administration can impair learning and memory in rats. Using high doses of baclofen led to the hypothesis that drugs that facilitate $\mathrm{GABA}_{\mathrm{A}}$ and $\mathrm{GABA}_{\mathrm{B}}$ neurotransmission can impair memory in experimental animals (Brion 1993). In our experiments, we tested this hypothesis for lower (therapeutic) doses of baclofen administered or different lengths of time.

The results of the Acquisition test showed that the latency time and distance needed to reach the platform were shortened during the six days of the learning phase in all tested groups. This phenomenon was observed in all parts of the study - for short-term administration of baclofen, given simultaneously with the start of behavioral testing (0D) as well as for long-term administration in which the animals were treated for two weeks (14D) or one month (1M) before testing in the MWM. In these three parts of the study there were no significant differences in the learning levels between the animals treated with baclofen, regardless of dose, and controls. Additionally, swim speed was observed to be independent of dose and duration of treatment for all groups. In general, it can be said that baclofen did not affect spatial learning at any of the tested doses and was not affected by short-term or long-term administration. In our experiments, baclofen was administered subcutaneously after completion of behavioral testing.

The Probe test, in the OD part of the study revealed that the highest dose of baclofen $(10 \mathrm{mg} / \mathrm{kg})$ reduced the time spent in the correct MWM quadrant compared with controls and compared to animals 
receiving lower doses of baclofen $(1 \mathrm{mg} / \mathrm{kg}$ and $5 \mathrm{mg} / \mathrm{kg})$. On the other hand, the animals receiving the highest dose of baclofen $(10 \mathrm{mg} / \mathrm{kg})$ spent significantly more time in the opposite quadrant compared to the control group and the groups treated with lower doses of baclofen. Long-term application of baclofen (14D and 1M parts of the study) resulted in the same amount of time spent in the correct quadrant by all animals. Moreover, there was no significant difference between groups relative to the time spent in the opposite quadrant.

The effect of baclofen on spatial learning was investigated in several previous studies using different learning paradigms. McNamara and Skelton (1996) reported the effect of systematic subcutaneously administered baclofen on learning in the MWM. They found that baclofen at a dose of $1 \mathrm{mg} / \mathrm{kg}$ had no impact on latency or distance traveled. Baclofen at $3 \mathrm{mg} / \mathrm{kg}$ initially impaired learning, but the effect wore off and final results approached the same learning level as the control group. The group treated at a dose of $6 \mathrm{mg} / \mathrm{kg}$ had a significantly longer average latency and longer average travel distance, and reduced swim speeds. Nakagawa and Takashima (1997) and Nakagawa et al. (1995) showed that baclofen at a dose of $4 \mathrm{mg} / \mathrm{kg}$ increased latency times to reach the platform, but the studies did not assess the effect of baclofen on swim speed. In the above mentioned studies, baclofen at the highest tested doses (in McNamara and Skelton 1996) $6 \mathrm{mg} / \mathrm{kg}$, in (Nakagawa et al. 1995, Nakagawa and Takashima 1997) $4 \mathrm{mg} / \mathrm{kg}$ ) decreased the time spent in the correct quadrant during the probe test. McNamara and Skelton (1996) also reported that the group treated with baclofen at $6 \mathrm{mg} / \mathrm{kg}$ spent the majority of their time in opposite quadrant.

The difference between our results and the results presented in the mentioned articles (McNamara and Skelton 1996, Nakagawa et al. 1995, Nakagawa and Takashima 1997) could have been caused by several factors. In the second and third part of our study, baclofen was given for 14 days and 1 month prior to behavioral testing in the MWM and the length of exposure to baclofen could have played an important role regarding the final effect of baclofen. The first part of our study (0D) had identical length (six day) of baclofen administration as in the paper by McNamara and Skelton (1996) and was similar in length to that used by the other authors (Nakagawa et al. 1995, Nakagawa and Takashima 1997) (4 consecutive days). However, other differences in method can lead to the mentioned divergence. In the mentioned studies (McNamara and
Skelton 1996, Nakagawa et al. 1995, Nakagawa and Takashima 1997), baclofen was administered shortly prior to behavioral testing. In our study, baclofen was administered after the behavioral task. Our approach attempted to minimize or prevent any possible effects of acute baclofen administration on motor function. This design difference could explain the differences in swim speed. Another highly significant difference was the number of training trials, which the animals underwent each day during the learning phase. In our study, the animals were placed in the MWM at one of four positions (in the order of $\mathrm{N}, \mathrm{S}, \mathrm{E}, \mathrm{W}$ ) using two repetitions (8 trials) unlike the mentioned study, where animals underwent only 4 trials. The animals were also given more time to consolidate the learned task.

Our results from the Re-acquisition showed that rats treated only during behavioral testing $(0 \mathrm{D}$ part of the study) with the highest dose of baclofen $(10 \mathrm{mg} / \mathrm{kg})$ traveled significantly longer distances and had longer latencies compared to controls group. This result was in agreement with a previous study, in which baclofen, injected at a dose of $10 \mathrm{mg} / \mathrm{kg}$ immediately after training trials, was disruptive relative to passive avoidance retention (Swartzwelder et al. 1987). This phenomenon was observed only during short-term administration of baclofen. Long-term application of baclofen (14D and $1 \mathrm{M}$ parts of the study) did not lead to significant differences between groups.

This work reveals that memory was influenced but only at the highest doses of baclofen and only for a temporary period. This conclusion is in line with previously published clinical cases (Grande et al. 2008, Sandyk and Gillman 1985) in which the above-described phenomenon was detected even with different methods of administration. Detailed long-term clinical cases addressing this topic are not available. Our results suggest that gradual titration of doses up to therapeutic levels could represent a clinically useful method to minimize or even prevent memory problems associated with baclofen.

All animals were able to learn the task, namely to find the hidden platform within a specified time limit, independent of dose or duration of baclofen treatment. In the probe test, the animals given the highest dose of baclofen (acute dose) spent less time in the correct quadrant, i.e. where the platform was located. In the Re-acquisition test, results found that baclofen impaired retention of learned tasks in a dose and duration dependent fashion. In clinical practice, our experimental results suggest that gradual dose titration to achieve 
a target dose, could be an effective method to reduced adverse effects associated with baclofen, including potential learning disabilities and memory difficulties.

\section{Conflict of Interest}

There is no conflict of interest.

\section{Acknowledgements}

This study was support by grant GAUK 1362913 and Progres Q37. We thank MUDr. Kataryna Nohejlová, Ph.D. and doc. RNDr. Anna Yamamotová, CSc. for statistical analysis. We also thank Mgr. Mária Ševčiková, Mgr. Eva Macúchová and Mgr. Ivana Hrebičková for their assistance.

\section{References}

AROLFO MP, ZANUDIO MA, RAMIREZ OA: Baclofen infused in rat hippocampal formation impairs spatial learning. Hippocampus 8: 109-113, 1998.

BENARROCH EE: GABAB receptors: structure, functions, and clinical implications. Neurology 78: 578-584, 2012.

BETTLER B, KAUPMANN K, MOSBACHER J, GASSMANN M: Molecular structure and physiological functions of GABA(B) receptors. Physiol Rev 84: 835-867, 2004.

BOWERY NG: GABAB receptor: a site of therapeutic benefit. Curr Opin Pharmacol 6: 37-43, 2006.

BOWERY NG: Historical perspective and emergence of the GABAB receptor. Adv Pharmacol 58: 1-18, 2010.

BOWERY NG, BETTLER B, FROESTL W, GALLAGHER JP, MARSHALL F, RAITERI M, BONNER TI, ENNA SJ: International Union of Pharmacology. XXXIII. Mammalian gamma-aminobutyric acid(B) receptors: structure and function. Pharmacol Rev 54: 247-264, 2002.

CAR H, WIŚNIEWSKI K: The effect of baclofen and AP-7 on selected behavior in rats. Pharmacol Biochem Behav 59: 685-689, 1998.

CASTELLANO C, MCGAUGH JL: Oxotremorine attenuates retrograde amnesia induced by post-training administration of the GABAergic agonists muscimol and baclofen. Behav Neural Biol 56: 25-31, 1991.

BRIONI JD: Role of GABA during the multiple consolidation of memory. Drug Dev Res 28: 3-27, 1993.

FRANEK M, VACULIN S: Role of GABA(B) receptor agonist baclofen in acute pain modulation during the early postnatal period. Pharmacology 84: 104-110, 2009.

FRANEK M, VACULIN S, ROKYTA R: GABA(B) receptor agonist baclofen has non-specific antinociceptive effect in the model of peripheral neuropathy in the rat. Physiol Res 53: 351-355, 2004.

GEORGIEV VP, YONKOV DI, KAMBOUROVA TS: Interactions between angiotensin II and baclofen in shuttle-box and passive avoidance performance. Neuropeptides 12: 155-158, 1988.

GRANDE LA, LOESER JD, SAMII A: Recurrent transient global amnesia with intrathecal baclofen. Anesth Analg 106: 1284-1287, 2008.

JACOBSON LH, KELLY PH, BETTLER B, KAUPMANN K, CRYAN JF: Specific roles of GABA(B(1)) receptor isoforms in cognition. Behav Brain Res 181: 158-162, 2007.

MACÚCHOVÁ E, NOHEJLOVÁ-DEYKUN K, SLAMBEROVÁ R: Effect of methamphetamine on cognitive functions of adult female rats prenatally exposed to the same drug. Physiol Res 62 (Suppl 1): S89-S98, 2013.

MCNAMARA RK, SKELTON RW: Baclofen, a selective GABAB receptor agonist, dose-dependently impairs spatial learning in rats. Pharmacol Biochem Behav 53: 303-308, 1996.

NAKAGAWA Y, ISHIBASHI Y, YOSHII T, TAGASHIRA E: Involvement of cholinergic systems in the deficit of place learning in Morris water maze task induced by baclofen in rats. Brain Res 683: 209-214, 1995.

NAKAGAWA Y, TAKASHIMA T: The GABA(B) receptor antagonist CGP36742 attenuates the baclofen- and scopolamine-induced deficit in Morris water maze task in rats. Brain Res 766: 101-106, 1997.

NOMURA S, KAGAWA Y, KIDA H, MARUTA Y, IMOTO H, FUJII M, SUZUKI M: Effects of intrathecal baclofen therapy on motor and cognitive functions in a rat model of cerebral palsy. J Neurosurg Pediatr 9: 209-215, 2012.

SAHA N, CHUGH Y, SANKARANARYANAN A, SHARMA PL: Effects of post-training administration of (-)-baclofen and chlordiazepoxide on memory retention in ICRC Swiss mice: interactions with GABAA and GABAB receptor antagonists. Pharmacol Toxicol 72: 159-162, 1993. 
SANDYK R, GILLMAN MA: Baclofen-induced memory impairment. Clin Neuropharmacol 8: 294-295, 1985.

SIDEL ES, TILSON HA, MCLAMB RL, WILSON WA, SWARTZWELDER HS: Potential interactions between $\mathrm{GABAb}$ and cholinergic systems: baclofen augments scopolamine-induced performance deficits in the eight-arm radial maze. Psychopharmacology (Berl) 96: 116-120, 1988.

STUCHLIK A, VALES K: Baclofen dose-dependently disrupts learning in a place avoidance task requiring cognitive coordination. Physiol Behav 97: 507-511, 2009.

SWARTZWELDER HS, TILSON HA, MCLAMB RL, WILSON WA: Baclofen disrupts passive avoidance retention in rats. Psychopharmacology (Berl) 92: 398-401, 1987.

ZARRINDAST MR, BAKHSHA A, ROSTAMI P, SHAFAGHI B: Effects of intrahippocampal injection of GABAergic drugs on memory retention of passive avoidance learning in rats. J Psychopharmacol 16: 313-319, 2002. 